\title{
Mucosal Immunology of Human Head
}

\section{Ibrahim M S Shnawa*}

College of Biotechnology, University of Qasim, Iraq

Submission: December 13, 2017; Published: January 08, 2018

*Corresponding author: Ibrahim M S Shnawa, Ph.D., University of Qasim, College of Biotechnology, Qasim, Babylon, Iraq, Email: ibrahimshnawa3@gmail.com

\section{Abstract}

The theme for the immune system of human head is of tripartite nature. The common mucosal immune compartment, the mononuclear phagocyte cell system and the transudate cellular and humoral factors of the systemic immunity. These compartments were covering; natural, cross-road adaptive immune events outcomes. Among which, the common mucosal immune system, which can be mapped into; CranialOral and nasal associate lymphoid tissue, conjunctiva and lachrymal associated lymphoid tissue ,Eustachian tube associate lymphoid tissue, nasopharyngeal associated lymphoid tissue as well as facial skin associated lymphoid tissue. In addition to the mononuclear phagocyte cell system and the natural immune barriers.

Keywords: Compartment; Cross-road; Cranial; Head; Immune; Lachrymal; Mucosal; Nasal; Oral

\section{Introduction}

In my previous communication [1] that has been concerning otolaryn-giologic mucosal immune compartment and the second

that was devoted to neck immunology [2]. The objective of the present micro- review was at the mucosal immunology of human head.

Biology

Table 1: The biology and Immuno-biology of Human head [3,7-9].

\begin{tabular}{|c|c|c|c|c|}
\hline Structure & Functions & Immune Functions & CMIS & Mononuclear Phagocyte \\
\hline Skull & Contour to other structure & & & Skull bone osteoclasts \\
\hline SAS: Brain & Nervous, cognition & Brain compartment & Cranium,CALT & Brain, Glial \\
\hline SAS: Eyes & Vision & Eye compartment & $\begin{array}{c}\text { Conjunctiva Associate, lymphoid tissue } \\
\text { EALT }\end{array}$ & Ear associated* macrophage \\
\hline SAS: Ears & Hear, Balance & Ear compartment & $\begin{array}{c}\text { Eustachian tube associated, lymphoid } \\
\text { tissue TALT }\end{array}$ & Ear associated* macrophage \\
\hline SAS: Nose & Smell, breath & Nose compartment & Nose, NALT & Nose associated ${ }^{*}$ macrophage \\
\hline $\begin{array}{l}\text { SAS: Oral } \\
\text { cavity }\end{array}$ & Eat & Oral compartment & Gut associated lymphoid tissue GALT & Oral associated macrophage \\
\hline SAS: Tonsil & Immune & $\begin{array}{c}\text { Tonsillar } \\
\text { compartment }\end{array}$ & $\begin{array}{c}\text { Waldeyers ring associated lymphoid } \\
\text { tissue }\end{array}$ & Tonsillar* macrophage \\
\hline SAS, Skin & immune & Skin compartment & Skin, SALT & Skin, Langerhans \\
\hline
\end{tabular}

SAS: Skull associated structures

*These macrophages are mostly of migratory nature.

Table 2: Common Mucosal Immune System of Human Head [7,15].

\begin{tabular}{|c|c|}
\hline Compartments & Associated Lymphoid Tissues \\
\hline Cranium, oral cavity, Nose & Cranial-Oral and Nasal \\
\hline Ear & Eustachian tube \\
\hline Eyes & Conjunctival and Lachrymal \\
\hline Cutaneous & Skin \\
\hline
\end{tabular}


Table 3: The effector sites of mucosa associated lymphoid tissue in human head $[7,15]$.

Epithelial lining of head associated structures

Stroma of the exocrine glands built in head associated structures

Lamina propria for the mucosae lining various structures associated with human head

From an at a glance view to the embryo-geny of human head, it starts as a primordium in the cephalic region of the embryo which then in utero developed to the characteristic human head. As a structure the head consist of the skull and the skull associated sub-structures which assigned to perform number of biologic functions like balance, cognition, hear, vision, smell and immune functions [3] (Table 1-3).

\section{Immunology}

The lymphatic system of human head constitute a vast network of an interconnected lymph vessels and their associated lymph nodes as well as countless lymph vessels. All these structures work together to; drain, filter and cleanse the interstitial fluids and destroy the harmful pathogens that may infect human head. The immune system of human head is formed from three main components.The common mucosal immune compartment, the mononuclear phagocyte cell system and the transcudate humoral as well as the migratory lympho-myeloid phagocytes from lymphoid origins. These compartments include natural, cross-road and adaptive immune events outcomes [4,5].

\section{Mucosal Immune System}

Mucosal immunology is one of the discipline of medical immunology. It concerned with the study of the mucosal immune system (MIS). MIS is composed of lymphoid tissues that are associated with mucosal surfaces of the; gastrointestinal, respiratory, and genitourinary tracts as well as skin [Though some debate]. Such a system has a number of features that differentiate it from the systemic lymphoid system. These are including; Mucosal immunoglobulin [IgA, $\operatorname{IgM}$ and to lesser extent IgG with tissue microenvironment dependent dominance], mucosa specific regulatory or effector $\mathrm{T}$ cells and mucosa-oriented cell homing system in several compartments .The primary function of MIS is to provide defense at mucosal surfaces. It can be divided into organized lymphoid tissue [M cells, Dome area cells, follicular T cells and follicular B cells] covering the gastrointestinal, respiratory and genitourinary tracts. And diffuse lymphoid tissue in lamina propria, epithelia, and stroma of exocrine glands compartments. The organized one is that acting as inductive sites and the diffuse one devoted to the interaction with immune cells [6].

\section{Mucosal Immune Mecanisms in Human Head}

Intranasal specific immune priming provides a productive means for inducing mucosal immunity at the head regions and distal mucosal tissues via common mucosal immune system. This induction of effector local cells in the nasal cavity is possible due to the proximity of the draining lymph nodes where initial encounter between antigen and lymphocyte occur. These tissues which support the induction of immunity for oral cavity associated salivary glands are collectively known as Craniumoral and nasal lymphoid associated tissues [CONAL]. The CONLAT encompasses the facial or parotid glands located posterior to the parotid gland, the submaxillary glands, the superficial cervical lymph nodes located anterior to the submaxillary glands located dorsal to the brachial plexus deep in the musculature of the neck. During the intranasal immunization, submaxillary lymph drain the nasal submucosa, cervical lymph nodes drain the nasal associate lymphoid tissue. Submaxillary lymph nodes, the brain and the parotid gland tissue are important in draining the skin of the head and neck as well as conjunctiva. High percentage of L select in+ lymphocyte in CONALT provide evidence that peripheral address in and homing receptors are important in lymphocyte trafficking to and from nasal passages and the salivary glands and the pathing of lymphocyte homing to the CONALT differ greatly from those of the gut. This means that not all mucosal tissues are phenotypically or functionally behave as intestinal tissue and variability among the lymphoid tissues of PLN, SMLN, CLN to effect distal mucosal immunity [7-9].

Conjunctiva associated lymphoid tissue in human eyes occur in different forms. First as diffuse lymphoid tissue of lymphocyte and IgA producing plasma cells formed a thin layer of lamina propria. The overlaying epithelium produce secretory component. Conjunctival sac s showed organized lenticular shaped follicles containing B cells and lympho-reticular cells embedded in LP. Conjunctival crypts do contained organized and diffuse lymphoid tissues. Lacrimal drainage system lymphoid tissues contained lymphoid tissue of same nature. High endothelial veinules present in all conjunctiva and lachrymal drainage system. SIgA is locally produced in human conjunctiva [10-12].

Ear associated lymphoid tissue was found Eustachian tube ,middle ear and mastoid process .Its presence was proved in those with otitis media. MALT showed wedge shaped distribution through middle ear and Eustachian tube. Bony parts of ET have shown MALT both in tympanic and pharyngeal portions. The presence of MALT in the ear is being age dependent and infants were found devoted from it. Ear infection mediate development of MALT $[13,14]$.

Nose associated lymphoid tissue NALT is taken as constitutive structure of nose local immune system and as a target tissue in strategies of local defense and as inductive site for vaccination .It is morphologically distinct from that of Waldeyers ring. Human NALT was found disseminated in the nasal mucosa with typical morphological features mainly in concha $[15,16]$.

\section{Mucosal Immune Compartments of Human Head Brain [7-9]}


Contour structure: The brain is encased within the bones of the skull. The brain consists of three main regions as cerebrum, cerebellum and the stem .The brain stem serves as the relay between the brain and the spinal cord.

Immune compartments: Cranium associated lymphoid tissue, glial cell system, and systemic migratory phagocyte cells.

Immune functions: Mucosal antibodies local defense functions against infections .Glial cell system produce local cytokines with phagocytic functions and served for brain tissue building as well as signaling molecules in local immune reactions.

\section{Eye [10-12]}

Contour structure: The eyeball is made up from three concentric coverings which encase the various transparent media and the photosensitive retina. This coat consists of two regions, transparent outer cornea and white the sclera. Sclera behind the cornea is opaque and mainly of protective function.

Immune compartments: Conjunctiva associated lymphoid tissue, lachrymal gland draining associated lymphoid tissue. Natural immune barriers like eye brow, eye lids and lachrymal apparatus.

Immune functions: Local mucosal immune responses, SIgA and the natural immune barriers.

\section{Ear $[13,14]$}

Contour structure: Human ear consists of external, medial and internal regions. The external ear includes the pinna and the external audatorymetus, the tube from the outer ear to the ear drum. The middle ear is the cavity between ear drum and the bony wall of the inner ear, it contains three small bones the incus, mallius and the stapes.

Immune compartments: Eustachian tube associated lymphoid tissue, ear wax, ear pinna.

Immune functions: Mucosal immune responses, natural immune barriers of infection and SIgA for local defense of ear infections.

\section{Nose [15,16]}

Contour structure: The gross topographic anatomy of human nose appeared as a protruding part of the face that bears nostrils.

Immune Compartments: Nasal associate lymphoid tissue as a part of the cranial-oral and nasal associated lymphoid compartment. As well as the nasopharynx associated lymphoid tissue.

Immune functions: Local nose immune responses. Mucosal inductive site. SIgA prevents local nasal infections.

\section{Oral cavity $[17,18]$}

Contour structure: The mouth, it is located at the beginning of the gastrointestinal tract. It is enclosed on the sides by the lips and checks, above by the hard palate and the soft palate and below by the floor of the mouth and the tongue .the floor of the mouth lies in a horseshoe around the tongue and is continuous with the gingiva and tongue.

Immune compartments: Oral associated lymphoid tissue as a part of the Cranial-Oral and nasal Associate lymphoid tissue. Migratory lympho-myeloid phagocyte cells.

Immune functions: Oral mucosal immune responses, oral immune tolerance and oral inductive site. SIgA for local oral defense of infection.

\section{Waldeyers Ring [19-21]}

Contour structure: It is mucosal associated lymphoid tissue MALT that consists of, lingual tonsils, palatine tonsils, tubal tonsils, nasopharyngeal tonsils and small collection of lymphoid tissues. These five tonsils surrounded the nasal and oral cavities of the head. Two lingual, two palatine and one pharyngeal. Each tonsil is a dense mass of lymphoid tissue covered in mucosal membrane continuous with the surrounding tissues.

Immune compartments: Tonsillar lymphoid tissue as a part Waldeyers ring associated lymphoid tissue.

Immune functions: Local trapper of the invading pathogens, mucosal inductive site, and local mucosal responses.

\section{Skin [22]}

Contour structure: Skin is composed of three layers. The epidermis, the outermost layer of the skin. The dermis contains tough connective tissue, hair follicles and sweat glands.The deeper subcutaneous tissue is made up of fat and connective tissue.

Immune compartments: Skin associated lymphoid tissue. It composed of; Langerhans cell system, keratinocytes, lymphoreticular cells, skin seeking lymphocytes and the skin draining lymph glands [As a term to mucosal compartment is still a subject of debate].

Immune functions: Local skin immunity against infections. Natural immune barrier

\section{References}

1. Shnawa IMS (2017) Otolaryngologic mucosal immune compartment. Otolaryngology Open Access Journal 2(1): 000147.

2. Shnawa IMS (2017) Neck surgery versus neck immunology. J Head Neck Spin Surg 1(2): 00102.

3. Clegg CJ (2000) Introduction to Advanced Biology. John Murray, London, pp. 410-434.

4. Abbas AK, Lichtmann ALL, Pillal S (2015) Cellular and Molecular Immunology. ( $8^{\text {th }}$ Edn), Elsevier, Canada, pp. 289-314.

5. Owon J, Punt J, Stanford SA, Jones PP (2013) Kuby Immunology. ( $7^{\text {th }}$ edn), Mecmillian, England, pp. 53-55. 
6. Strober W, Fuss IJ (2001) The mucosal immune System. In: Parslow TG Stites DP, Terr AI, Imboden JB (eds.), Medical Immunology. $\left(10^{\text {th }}\right.$ edn), Lange Medical Books, New York, pp. 204-214.

7. Csencsits KL, Jutila MA, Pascual DW (2002) Mucosal Address in expression and binding interaction with naïve lymphocytes vary among the cranial, oral and nasal associated lymphoid tissues. Eur J Immunol 32(11): 3029-3039.

8. Shnawa IMS (2015) Oral immune tolerance versus immune Silencing Mini-review. Am J Biomed Lif Sci 3(4-1): 7-9.

9. Shnawa IMS (2015) the interplay of the local microbiome with the oral mucosal immune compartment. Am J Biomed Lif Sic 3(4-1): 17-19.

10. Knop N, Knop E (2000) Conjunctiva associate lymphoid tissue in human eye. Invest Ophthalmol Vis Sci 41(6): 1270-1279.

11. Knop N, Knop E (2003) Eye associated lymphoid tissue is continuously spread through ocular surface from lachrymal canaliculi and lachrymal drainage system. Ophthalmologe 100(11): 929-942.

12. Knop N, Knop E, Claus P (2008) Local production of SIgA in the eye associated lymphoid tissues of normal human eye surface. Invest Ophthalmol Vis Sci 49(6): 2322-2329.

13. Kamimura M, Balaban CD, Sando I, Haginomori S (2001) Mucosa associated lymphoid tissue in the middle ear and Eustachian tube. Ann Otol Rhinol Laryngol 110(3): 243-247.

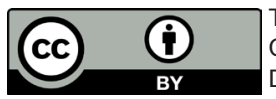

This work is licensed under Creative Commons Attribution 4.0 Licens

DOI: 10.19080/JHNSS.2018.02.555577
14. Matsune S, Takahashi, Sando I (1996) Mucosa associated lymphoid tissue in the middle ear and Eustachian tube in children. Int J Pediatr Otorhinolaryngol 34(3): 229-236.

15. Brandtzaeg P, Kiyono H, Pabst R, Russell MW (2007) Nomenclature of mucosa associated lymphoid tissues. Mucosal Immunol 1: 31-37.

16. Debertin AS, Tscherning T, Tonjes H, Kleenmann WJ, Toger HD, et al. (2003) Nasal associated lymphoid tissues frequency of localization in young children. Clin Exp Immunol 134(3): 503-507.

17. Shnawa IMS (2016) Oral Epithelial cytokines. Int J Vaccine Vaccin 2(2): 00026.

18. Shnawa IMS (2015) Oral immune cross roads. WJPR 4(12): 1766-1778.

19. Rashid TK, Shnawa IMS, Khayyat FD (2008) Infg, IL6, IL10, in immune response of children with reccurent bacterial tonsillitis. ZJMS 12(12): $11-17$

20. Rashid TK, Shnawa IMS, Khayyat FD (2008) Histological Study of human palatine tonsils in patients with recurrent bacterial tonsillitis. ZJMS 12(12): 11-17.

21. Shnawa IMS, ALAmidie BHH (2009) Immune state of patients with Streptococcus pyogenes tonsillitis, Fourth Congress of College of Science, University of Babylon, Special Issue.

22. Steilein JW (1989) Skin associated lymphoid tissue. Immunology Series 46: 73-96.

\section{Your next submission with Juniper Publishers will reach you the below assets}

- Quality Editorial service

- Swift Peer Review

- Reprints availability

- E-prints Service

- Manuscript Podcast for convenient understanding

- Global attainment for your research

- Manuscript accessibility in different formats

( Pdf, E-pub, Full Text, Audio)

- Unceasing customer service

Track the below URL for one-step submission https://juniperpublishers.com/online-submission.php 